\title{
The Anti-Gender Movement in Europe and the Educational Process in Public Schools
}

Roman KuHAR ${ }^{\star 1}$ AND Aleš Zobec ${ }^{2}$

$\approx$ Mass protests across Europe against marriage equality, reproductive rights, gender mainstreaming and sexual education have centralised in the past few years around so-called "gender theory". This theory is explained as a new threat to the "traditional family" and "natural masculinity and femininity", as it allegedly aims at cultural revolution: a post-binary gender world. Many of these debates (and concrete actions) are targeted at schools and the educational process. It is believed that "gender theory" is already being taught in schools, which will have detrimental consequences for pupils. Agents of the anti-gender movement claim that children are being sexualised and brainwashed by "gender theory".

Taking this debate as the starting point, we first examine the roots of the term "gender theory" and point to its nature as an "empty signifier". We then analyse the types of anti-gender actions across Europe that interfere with the educational process in public schools. Finally, we consider the role of parents and their right to intervene (or not) in the educational process. On the basis of the existing rulings of the European Court of Human Rights, we argue that the provision that parents are entitled to educate their children in accordance with their religious and moral beliefs does not mean that teachers in schools should avoid issues that might "morally distress" pupils or their parents, as long as schools avoid indoctrination, and providing the topics (like any other topics) are conveyed in an objective, critical and pluralistic manner.

Keywords: gender theory, gender ideology, public schools, educational process

1 * Corresponding Author. University of Ljubljana, Faculty of Arts, Department of Sociology, Slovenia; roman.kuhar@ff.uni-lj.si.

2 Secondary Preschool Education and Gymnasia Ljubljana, Slovenia. 


\section{Gibanje proti "teoriji spola" v Evropi in izobraževalni proces $\mathrm{v}$ javnih šolah}

Roman Kuhar in Aleš Zobec

$\approx$ Množični protesti po Evropi proti istospolnim porokam, reproduktivnim pravicam, politiki gender mainstreaming in spolni vzgoji so se $\mathrm{v}$ zadnjih letih osrediščili okrog tako imenovane »teorije spola«. Razumejo jo kot novo grožnjo »tradicionalni družini« ter »naravni moškosti in ženskosti «, ker naj bi domnevno vodila v kulturno revolucijo - v postbinarni spolni svet. Veliko teh razprav (in konkretnih akcij) je usmerjenih $\mathrm{v}$ šolski prostor in izobraževalni proces. Akterke_ji teh protestov trdijo, da se »teorija spola« že poučuje v šolah, kar naj bi imelo škodljive posledice za učenke_ce. Prav tako trdijo, da »teorija spola« otroke v šolah seksualizira in jim pere možgane.

Razpravo o "teoriji spola« v tem članku postavljamo v izhodišče naše razprave in najprej pokažemo na izvore tega termina, ki ga razumemo kot prazni označevalec. Nato analiziramo tipe intervencij akterk_jev tega gibanja v šolski prostor javnih šol v Evropi ter nazadnje razpravljamo o vlogi staršev in njihovi pravici, da posegajo (ali ne) v izobraževalni proces. Na osnovi obstoječih sodb Evropskega sodišča za človekove pravice trdimo, da pravica staršev, da svoje otroke vzgajajo skladno s svojimi verskimi in moralnimi prepričanji, ne pomeni, da naj se učiteljice_i v šolah izogibajo temam, ki bodo mogoče »moralno pretresle« učenke_ce ali njihove starše, dokler se šole pri obravnavi teh tem izogibajo indoktrinaciji in so te teme (ali katere koli druge) prikazane na objektiven, kritičen in pluralen način.

Ključne besede: teorija spola, ideologija spola, javna šola, vzgojni proces 


\section{Introduction}

In the recent years - particularly since the mass protests by Manif pour tous in France against marriage equality in 2013 - an increasing number of groups and initiatives have been organised in resistance to what previously appeared to be an irreversible process of achievement of gender equality and sexual rights in the Western world (but also elsewhere). Their targets include anything from marriage and gender equality, abortion, reproductive rights, sex education, gender mainstreaming and transgender rights, to antidiscrimination policies and even the notion of gender itself. The basic idea that connects all of these actors is the notion of "gender theory" or "gender ideology", ${ }^{3}$ which functions as an empty signifier (Mayer \& Sauer, 2017), as symbolic glue (Kováts \& Põim, 2015), or simply as a multi-purpose enemy, which can be shaped in different ways to fit into the concrete goal of a political protest.

This resistance across Europe should not be understood merely as a continuation of previous forms of (conservative) opposition to the human rights pertaining to intimate (Plummer, 2003) and sexual citizenship (Richardson, 2000) policy debates; they are new manifestations of resistance, shaped by new forms of organisation, new types of mobilisation and new discourses that seek to address wider audiences and not only traditional circles of conservative groups.

Despite the fact that the term "gender theory" has emerged only recently, its ideological background has been in the making since the mid 199os, primarily in the context of the Roman Catholic Church. As shown by recent investigations into the roots of the anti-gender movement, the Vatican has been instrumental in manufacturing the notion itself and in spreading it around Europe and globally (Paternotte, 2015).

One of the most important targets of the anti-gender movement in Europe is public schools and the educational process. It is believed that "gender theory" has "leaked" into public schools and that pupils are being sexualised and brainwashed by radical feminist ideology and homosexual propaganda. For these reasons, groups of concerned parents are being organised across Europe to protest against the alleged infringement of their right to educate their children in accordance with their religious and philosophical convictions ( $\mathrm{Pa}-$ ternotte \& Kuhar, 2017b).

Taking these developments as the starting point, the aim of the present article is threefold. First, we examine the emergence and interpretation of the term "gender theory" and why it has such a strong mobilising effect. We then

3 Both terms are used by anti-gender activists. In this article we use them interchangeably. 
discuss the types of protests anti-gender movements across Europe use to protest against "gender theory" in the educational process in public schools. These two sections are based on a research project comparing these movements in twelve European countries, carried out between 2014 and 2017 (Kuhar \& $\mathrm{Pa}$ ternotte, 2017). The research focused on a critical analysis of the movement's discourse, mobilisation strategies and actors. Empirically, it was based on an analysis of the movements' webpages, public statements and debates, leaflets, media articles, YouTube videos, etc. in each national context. ${ }^{4}$

Finally, we consider the role of parents and their right to intervene (or not) in the educational process when "difficult topics" such as gender equality or sexuality are discussed. In reality, these protests are not a totally new phenomenon: parents have complained about certain topics - particularly sex education - in the past, with some of the cases ending up at the European Court of Human Rights. What is new is the magnitude of the protests, such as the French or Italian appeals to "concerned parents" to keep their children out of school for a day in order to protest against "gender theory". Such protests put immense pressure on school authorities and on teachers themselves.

Despite the aforementioned differences, we believe that the existing judgements of the European Court of Human Rights are still a valid interpretation of Article 2 of the Protocol to the Convention for the Protection of Human Rights and Fundamental Freedoms (1952), which compels the State to "respect the right of parents to ensure such education and teaching in conformity with their own religious and philosophical convictions".

On the basis of an analysis of these rulings, we will argue that the provision that parents are entitled to educate their children in accordance with their religious and moral beliefs does not mean that teachers in schools should avoid issues that might "morally distress" pupils due to their particular value system. In this sense, public schools and especially teachers - while respecting the particularities of value systems - should strongly commit to the framework of shared values and norms that derive from human rights and should prevent mass populist attempts of anti-gender movements to intervene in the educational process.

4 We are indebted to the following researchers: Austria (Stefanie Mayer and Birgit Sauer), Belgium (Sarah Bracke, Wannes Dupont and David Paternotte), Croatia (Amir Hodžić and Aleksandar Štulhofer), France (Michael Stambolis-Ruhstorfer and Josselin Tricou), Germany (Paula-Irene Villa), Hungary (Eszter Kováts and Andrea Petö), Ireland (Mary McAuliffe and Sinead Kennedy), Italy (Sara Garbagnoli), Poland (Agnieszka Graff and Elżbieta Korolczuk), Russia (Kevin Moss), Spain (Monica Cornejo and J. Ignacio Pichardo). 


\section{The roots of "gender theory"}

In January 2013, France saw one of the largest protests in recent history. According to some estimates, nearly one million people protested against the French government, which had opened up the institution of marriage for same-sex couples. Some of the protesters held banners saying "Stop gender" or "Stop gender ideology". The notion of "gender ideology" was seen as a symbol of a moral crisis, represented by the fact that same-sex couples are treated equally to opposite-sex couples. However, "gender ideology" - which is in some countries worded as "gender theory" or, primarily in German-speaking countries, as "genderismus" (in an allusion to "kommunismus") - represents much more than just resistance to marriage equality. As it is never clearly defined, its meaning is slippery. As such, it creates the impression of a conspiracy theory and functions as an "empty signifier" (Mayer \& Sauer, 2017) that can represent everything and anything from marriage equality and sexual education to reproductive and adoption rights and abortion.

The emergence of the notion of "gender theory" and the related discourse can be traced back to developments after the 1994 UN Conference on Population and Development in Cairo and the World Conference on Women in Beijing in 1995. At that time, the term "gender" started to emerge in the official documents of these conferences, replacing the more essentialist term "sex", in order to show that gender non-equality is not a result of biological differences, but rather primarily of socially constructed differences between genders (Buss, 2004).

During these conferences, however, the Holy See expressed explicit reservations about the term "gender" and insisted that the final documents of both conferences use the term "sex". For the Holy See, gender, or the idea that male and female are socially constructed categories, goes against their ideas of the "natural family" in which both man and woman have their own distinct roles, as defined by their biological differences (primarily in terms of reproduction) (ibid., 2004). For these reasons, the Vatican tried to promote the idea of "equal dignity" of men and women, rather than equal rights regardless of gender (i.e., gender equality). Such an interpretation is built on John Paul II's theology, which insists on sexual differences between men and women and on their complementarity. Similarly, Cardinal Ratzinger lamented the "trivialisation of sexual differences" as early as in 1985 (Paternotte, 2015).

In the aftermath of both conferences, the first discussions on gender as a hidden plan of radical feminists and LGBT activists emerged. Gender was interpreted not only as a social construction of the sexes, but also as a "strategic tool" to establish a post-gender society that would either dismiss the importance of 
gender or would establish a gender order that goes beyond the binary gender system. These authors - such as American pro-life journalist Dale O’Leary (1997), French priest and psychoanalyst Tony Anatrella (2015) and later German sociologist Gabriele Kuby (2016) - all claimed that gender aims to destroy masculinity and femininity, to go beyond the "natural complementarity of men and women" and consequently to destroy the "natural family". These interpretations are still at the core of what was later termed "gender theory", which is now understood to be the ideological paradigm of more or less any gender equality and sexual citizenship policies (Paternotte, 2015).

"Gender theory" started to catch on as a new buzzword and received mainstream attention around 2012 and 2013, particularly during the French protests of Manif pour tous. Similar resistance had, however, occurred before, such as the protests against marriage equality in Spain in 2005, followed by the so-called Family Day in Italy in 2007, which was organised to protest against the Italian government's intention to adopt civil partnership legislation (DiCo) for samesex couples. Later, the "family day" became one of the protesting structures of anti-gender movements around Europe. Slovenia saw such protests against the new Family Code, including a Family Day, in 2010. In Croatia, protests against the sex education module took place around the same time. In Poland, the "gender ideology" debate emerged around deliberations on gender violence and the ratification of the Istanbul Convention, while in Slovakia gender was one of the key words during their referendum campaign in 2015 on the definition of the family and the rights of same-sex couples (Paternotte \& Kuhar, 2017a).

During all of these protests, "gender theory" became denounced as the main ideological base of all of these progressive policies. In other words, "gender theory", alluding to the idea that there is a coherent body of scientific work known as "gender theory" (which is not the case), became a synonym for some kind of conspiracy theory, aiming at a cultural revolution in which biological facts about men and women will be denied and fluidity of gender will be promoted. "Gender theory" is therefore constructed as a project of social engineering where men are no longer masculine and women are no longer feminine and one is free to choose one's own gender and sexual orientation, even "several times a day" (Cestnik 2013; Debevec 2015; Hodžič \& Bijelić, 2014).

Some Catholic intellectuals, such as Tony Anatrella (2015), claim that "gender ideology" is a new leftist ideology, which has succeeded Marxist ideology. The battle no longer exists "in the relation between the bourgeoisie and the capital against the working class, but rather in the relation between men and women" (Strehovec, 2013, p. 238). Primarily in the context of Eastern Europe, "gender ideology" is often explained as a neo-colonial project in which 
the decadent West seeks to impose its gender delusion upon the rest of the world (Graff \& Korolczuk, 2017b). This is one of the populist strategies of the anti-gender movement to revive the unpleasant memories of former totalitarian regimes. Polish Bishop Pieronek, for example, claimed "Gender ideology is worse than communism and Nazism put together" (Graff \& Korolczuk, 2017a).

The term "gender theory" increasingly became a matter of fact: it was picked up by the mainstream media, politicians refer to it in their political speeches - either to denounce it or to frame their arguments in line with "gender theory" argumentation - and eventually it also became a household word among the general population. As it is simplistically explained as a theory that goes against the common-sense understanding of sex as a biological category, it counts on people's deeply rooted anxieties about (homo)sexuality and gender roles, thus creating the desired populist effect: aversion, but also anger and moral panic.

The most fascinating aspect of this phenomenon is that the "boring scientific-sounding term" of "gender theory" has been able to become such a strong and effective mobilising tool. This can be partly explained by the fact that "gender theory" is said to be a product of the ruling elites. Just like "gender theory", elites function as an empty signifier, representing either politicians, feminists, LGBT activists or just anyone who struggles for gender equality. These groups are seen as corrupt elites, who are producing such ideas in the ivory towers of universities and (trans)national political structures, and are entirely detached from ordinary people.

The fact that most of the aforementioned protests took place during the economic crisis, in the face of strict austerity measures and the rise of populism in Europe, helped strengthen the perception of a gap between elites and ordinary people. The movement is successful because it appeals - much like the populist parties and groups around Europe (Lazaridis et al., 2016) - to the anxieties of people about the future of their family, and particularly their children. The "innocent child" is at the centre of the anti-gender discourse, which is based on what Wodak (2015) calls the "politics of fear".

With its focus on corrupt elites, the anti-gender movement has provided people with the promise of a better future. The future, however, is in the past: our societies, they claim, should return to the natural order of things, whereby men are men and women are women and both are equally respected, but are not equal.

The anti-gender movement includes actors who go beyond religious affiliations. In fact - as stressed by Kováts and Põim (2015) - the movement is a symbolic glue that makes cooperation between different actors possible, despite 
the differences in their basic ideological framework. At the core of "gender ideology" as a glue that links and unites as diverse actors as family associations, prolife groups, some religious gay actors and radical nationalist parties, is the image of the "innocent child", and consequently family and nation. Furthermore, the joint actions of these actors are inspired by the same target: corrupt elites whose (gender) ideology is constructed as a new totalitarian ideology that aims to destroy masculinity and femininity, to go beyond the natural complementarity of men and women, thus weakening the basis of the "natural family" and, by consequence, the nation itself (Hodžič \& Bijelić, 2014; Paternotte \& Kuhar, 2017b).

Groups and actors who are united in their struggle against "gender ideology" find gender to be a common, unifying ground, as gender is constructed as an attack on either nature (religious actors), nation (nationalistic actors) or normality (conservative actors). Despite some convergences between the actors, these are the main distinct entrance points for anti-gender groups. In other words, "gender ideology" is a common framework that squeezes different discourse into one big threat to which different actors can connect (Paternotte \& Kuhar, 2017b).

The anti-gender movement presents itself as modern, young and hip. In most cases, the movement tries to hide its religious connections and create a secularising self-image that cannot be reduced to previous forms of conservative resistance against gender equality and sexual rights. They also increasingly create international coalitions, such as in the case of the European citizens' initiative to protect marriage and the family: Mum, Dad \& Kids. ${ }^{5}$

\section{The anti-gender movement and public schools}

One of the important targets of the anti-gender movement is knowledge production. This is a struggle over the legitimacy of academic work, particularly of gender and related studies. In Poland (Graff \& Korolczuk, 2017a) and France (Stambolis-Ruhstorfer \& Tricou, 2017), but also elsewhere, gender departments and gender studies courses at universities have been attacked and denounced as nests of "gender ideology" and non-scientific work. Gender studies are criticised as being non-academic, ideological and in conflict with the allegedly unquestionable findings of biology, such as differences between male and female brains. The anti-gender movement therefore has ambitions to become an alternative field of knowledge production.

Similarly, one of the targets of the anti-gender movement in Europe is public schools, which are said to already include "gender theory" in their

5 Initiative Mum, Dad and Kids, see: http://www.mumdadandkids.eu/. 
curricula. Different types of actions have been organised to resist teaching on gender equality in schools. Civil initiatives of so-called "concerned parents" have tried to put pressure on school authorities and teachers to not address certain topics, such as same-sex families, the social construction of gender roles, sex education, homosexuality and similar. In France, for example, they organised an online petition against an animated film for primary schools entitled Baiser de la lune, which showed two male fish in love (Stambolis-Ruhstorfer \& Tricou, 2017), while in Italy they succeeded in withdrawing books that address family diversity from some public primary schools (Garbagnoli, 2017).

In some countries, such as Poland and Croatia, where religious education is an important part of the public school system and the Catholic Church has been an important actor within it, the anti-gender backlash can also be understood as a reaction to the interpretation that Church values and teaching about the complementarity of the sexes and the "natural family" are being questioned, and the role of the Church is being diminished (cf. Grabowska 2014).

Research into anti-gender campaigns in Europe (Kuhar \& Paternotte, 2017) has found three types of resistance against public schools, attempting either to put pressure on school authorities and ministries of education to prohibit certain topics from being discussed in schools, or to concretely intervene in the educational process itself. These types of resistances include: (1) general protests against sexual education, (2) denouncement of certain textbooks as promoting "gender ideology", and (3) organised mass protests to keep children home from school.

The opposition to sex education in school is not new. Opponents claim that such education sexualises children at an early age and normalises homosexuality, particularly in cases where sexuality is not presented only in a negative way (i.e., prevention of sexually transmitted diseases), but also in a positive way (i.e., enjoyment of sexuality). Furthermore, their efforts are based on the idea that children should be prevented from access to any kind of information on sexuality. It is believed that talking about sexuality would be detrimental to them, as children are understood as being without sexuality. Robinson (2008) points out that such "protection" makes children even more vulnerable, as they are prevented from access to relevant information about sexuality that would help them to become competent adults.

One of the most visible examples of this is Croatia, where the Croatian anti-gender movement came into being precisely around the debates on health education (which includes a module on sex education), which started as early as in 2006. Besides the clash of the approaches to sex education - abstinencebased programmes vs. holistic protection-based programmes - some claim 
that sex education negatively affects pupils' sexuality and increases teenage pregnancies (Bijelić 2008; Kuhar 2015). The most contentious issues in these debates, however, seem to be gender equality and positive representations of homosexuality (Hodžič \& Štulhofer, 2017).

Similar protests, organised by the anti-gender movement, can be seen in other European countries, too. In 2015 in Austria, the Initiative wertvolle Sexualerziehung (Initiative for Valuable Sexual Education), in close cooperation with political parties and pro-life activists, organised a petition protesting against sex education and gender-sensitive language in Austrian schools (Mayer \& Sauer, 2017). Demonstrations against sex education in school were also organised in Germany, where some groups promote homeschooling in order to avoid "gender theory" and to "weaken public (state driven) interference in what they consider 'private' matters" (Villa, 2007). Similarly, in Poland, sex education is presented as an unwanted intervention in the individual's privacy and often compared to the previous political regime, which tried to gain full control over people's private lives. A huge rally labelled "Stop Depravation in Education” was organised in 2015 to prevent changes in the existing sex education curricula (Graff \& Korolczuk, 2017a).

The second type of protests are organised around the creation of episodes of moral panic, in which certain textbooks that address gender equality or promote analysis through gender lenses are scrutinised and accused of indoctrinating children in schools from an early age, usually without the knowledge of parents. Such interventions are usually publicly declared by certain MPs who are close to the anti-gender movement, in order to put pressure on ministries of education to prohibit these books in school.

Anti-gender groups also call on "concerned parents" to investigate textbooks and school curricula and identify where "gender ideology" has leaked into "our schools". They are asked to report such examples to anti-gender groups, who then react by putting pressure on schools or a particular teacher to degender their teachings. In Italy, special "anti-gender phone lines" were introduced by public authorities to enable parents to report instances of "gender ideology" found in education programmes (Garbargnoli, 2017).

One example of the "anti-gender examination of textbooks" is a Hungarian history textbook that presents history through the lens of gender. A Fidesz MP denounced the textbook as promoting "gender ideology" during a parliamentary debate (Kováts \& Pető, 2017).

The French parliament saw identical concerns in 2011, when a conservative MP warned against the intention of the French Ministry of Education to include the difference between sex and gender in high school biological 
textbooks. This was seen as a penetration of foreign (i.e., American) theory into French textbooks, and as such was regarded as damaging for pupils (StambolisRuhstorfer \& Tricou, 2017).

In Slovenia, the booklet Ljubezen je ljubezen (Love is Love), which was used by Amnesty International during their extracurricular workshops in schools on human rights on the basis of "gender identity" and sexual orientation, was discussed in parliament as evidence that "gender theory" is being spread among "our children in schools" without parents' consent, and even without parents being informed. Pressure was put on the Minister of Education to prevent the use of the booklet, which is, according to the anti-gender movement, "aimed at the re-education of children in accordance with 'gender theory', which does not recognise the existence of natural female and male sexes" (24kul, 2016).

Similarly, in Poland, some anti-gender activists organised themselves around a protest against a handbook called Równościowe przedszkole (Equality Kindergarten), which is based on feminist ideas of gender equality. The handbook is interpreted as promoting masturbation, while sex educators are rumoured to force boys to wear dresses (Graff \& Korolczuk, 2017). Much like in Slovenia, the handbook is seen as evidence of a plan to destroy innocent children, who are to be confused about gender roles at an early age (Korolczuk, 2014).

Finally, in addition to (online) petitions and public protests against addressing diversity and gender equality in schools and textbooks, anti-gender activists have also organised concrete actions that have interfered with the educational process itself. In 2014, the French anti-gender movement organised the action Journée de Retrait de l'École (Keep Your Child Home from School Day) in order to protest against the Ministry of Education and its intention to introduce an experimental curriculum on gender equality in schools. They used social media to call on parents - particularly in working class families of colour - not to allow their children to go to school. This created a kind of moral panic and some pupils stayed at home for several days (Stambolis-Ruhstorfer \& Tricou, 2017).

Inspired by the French protests, the Italian anti-gender movement organised a similar action in 2014. Using WhatsApp and other social media, the Italian Association of Catholic School Parents called on parents to withdraw their children from public schools once a month in order to protest against colonisation by "gender ideology" in Italian schools (Garbargnoli, 2017). 


\section{The rights of parents and the educational process}

The increasing anti-gender resistance targeting of public schools exceeds previous occasional protests by some parents who wanted their particular value system to be installed in public school curricula. The magnitude of the resistance, and particularly the convergence of resisting anti-gender strategies across Europe, inevitably gives rise to the question of how to reconcile the specific and particular value system of some parents (and their children) and the educational process in public schools.

We assume that this question can be answered by an evaluation of the existing court rulings of the European Court on Human Rights, which has previously dealt with similar examples of parents who have tried to prevent - or have even successfully prevented - their children from attending school due to their particular value system, despite the fact that the anti-gender movement is generally aiming at the exclusion of some topics for all pupils, not just for their own.

Our starting point is the Resolution on the European dimension of education: teaming and curriculum content (1991), which stipulates that human rights, plural democracy, tolerance, solidarity and rule of law are the most basic values enabling human coexistence. This means that this framework, particularly the human rights framework, should be the most general and basic framework of the public education system in Europe, or generally in a postmodern society, which is characterised by the co-existence of different value and belief systems, but which must welcome all pupils in public schools equally.

As demonstrated by Lefort (2001), human rights do not determine and define the concrete form of an "ideal life"; on the contrary, they represent one of the conditions for coexistence in postmodern diversity. The answer to the question, what is "the ideal life" is therefore left to be determined by each individual him/herself.

The adoption of human rights is a prerequisite for the coexistence of particularities in our value systems, whereby it should be noted that the predominant value system is still a particular one. For example, even if, in a given society, there is a perception of the "ideal life" that is accepted by the majority, this idea cannot be understood as applying to all, despite the fact that it is supported by the majority. In short, it is necessary to distinguish between the concept of particular, which includes some majority beliefs and values, and the concept of common, which we all share and is defined as such by international treaties, resolutions and legislation, such as those pertaining to human rights.

This is precisely the key distinction established by the idea of human rights. Once we adopt it as a common basis, it creates a legitimate distinction 
between what is understood as common and what is particular. Such a distinction is also a helpful tool enabling teachers and school authorities to make decisions in the context of conflicts rooted in values and morals, such as that initiated by the anti-gender movement. Since one of the basic human rights is the principle of non-discrimination, irrespective of any personal circumstances, human rights demand tolerance and respect for diversity. This means that teachers are required to provide information and knowledge that is based on scientific findings, while at the same time striving for the implementation of the principle of non-discrimination and respect for diversity, even if this results in some pupils being "morally distressed" by new information or knowledge (Kovač Šebart \& Krek, 2009).

In the past, some parents appealed to the European Court of Human Rights, claiming that their right to education, as defined by Article 2 of the Protocol to the Convention for the Protection of Human Rights and Fundamental Freedoms (1952), had been infringed: "No person shall be denied the right to education. In the exercise of any functions which it assumes in relation to education and to teaching, the State shall respect the right of parents to ensure such education and teaching in conformity with their own religious and philosophical convictions."

But what exactly does this provision mean for public schools in Europe? Does it mean that the State is required to provide education that is in line with parents' religious and philosophical convictions?

The most important ruling in this context is the case of Kjeldsen, Busk Madsen and Pedersen v. Denmark from 1976. In 1970, Denmark introduced compulsory sex education in order to "reduce the increased prevalence of unwanted pregnancies and promote respect for others". Some parents, including the complainants, believed that compulsory sex education was not in accordance with their Christian beliefs. "They considered that sex education raised moral questions and so preferred to instruct their children in this sphere. They petitioned on multiple occasions to get their children exempted from sex education. However these requests were not met, resulting in some of the applicants withdrawing their children from their respective State schools" (Right to Education Project, 2013).

In a more recent case - Willi, Anna and David Dojan v. Germany and four other applications - the applicants (members of the Christian Evangelical Baptist Church) requested that their children should be exempted from sex education, which is part of the curricula of primary school. The applicants stated that their children "had been used to modest and chaste sexual behaviour at home and did thus not have the necessary maturity to receive the envisaged sex 
education", which would lead to the "premature sexualisation" of the children (ECHR, 2011). A couple of years later, the applicants prevented some of their children from attending a school theatre workshop entitled "My Body is Mine", which was organised for the purpose of preventing sexual abuse. Parents stated "that it was incompatible with their religious convictions to make a child's own feelings and will the basis of his or her sexual behaviour, as this would encourage them to act according to their sexual desire like an adult, lose their sense of shame and engage in sexual acts with adults. The biblical doctrine of chastity, limiting sexuality to matrimony, constituted sufficient protection against sexual abuse" (ibid.).

In both cases described above, the European Court of Human Rights came to the same conclusion. The Court ruled that compulsory sex education in public schools as such does not violate parental freedom to educate their children according to their religious and philosophical convictions. In the latter case, it reiterated that Article 2 of the Protocol "aims at safeguarding the possibility of pluralism in education, a possibility which is essential for the preservation of the 'democratic society' as conceived by the Convention" (ibid.). Article 2 as a whole does not prevent States from disseminating objective information "for otherwise all institutionalised teaching would run the risk of proving impracticable" because "it seems very difficult for many subjects taught at school not to have $[\ldots]$ some philosophical complexion or implications" (ibid.). However, the knowledge must be conveyed in an "objective, critical and pluralistic manner", without pursuing the aim of indoctrination. The Court also stated that the applicants "were free to educate their children after school and at weekends and thus their right to educate their children in conformity with their religious convictions was not restricted in a disproportionate manner" (ibid.).

Both rulings stipulate that parents do not have the right to prevent those issues that might be in conflict with their personal beliefs from being discussed in schools: "The Convention does not guarantee the right not to be confronted with opinions that are opposed to one's own convictions" (ibid.). Identical court decisions were ruled in many other similar cases, as well (Appel-Irrgang and others v. Germany, 2009; Folgero and others v. Germany, 2007; Hasan and Eylem Zengin v. Turkey, 2007).

Another decision of the European Court of Human Rights from 1982 (X. and Y. v. the UK) is also important in this context. In this case, the complainants claimed that the State should financially support a private school (Waldorf school) that they had chosen due to their personal philosophical convictions. The court decision stipulates that the State is not obliged to either found or finance private schools that serve particular religious or philosophical beliefs. 
Public schools must, however, respect the particular beliefs of parents. According to the interpretation of the European Court, the latter means that public schools may not indoctrinate children contrary to the beliefs of their parents; at the same time, the educational process must comply with the principles of criticism, objectivity and pluralism. Following this judgment, particular religious or philosophical beliefs must be respected in public schools, but that certainly does not mean that the educational concept of public schools should follow the particular belief systems of (some) parents (Cf. Kodelja 1995; Kovač Šebart 2015; Kovač Šebart \& Kuhar, 2017).

\section{Conclusion}

According to the rulings of the European Court of Human Rights, the "moral distress" experienced by some pupils when faced with topics such as gender equality or homosexuality does not mean that the teaching of such topics in public schools is in violation of Article 2 of the Protocol to the Convention for the Protection of Human Rights and Fundamental Freedoms, nor does it mean that public schools should avoid dealing with issues that have a philosophical or religious foundation. Pupils can be confronted with facts and opinions that differ from their beliefs (and as a rule this inevitably happens) and teachers should not avoid such topics; they should, however, respect the diversity of beliefs in school.

There is another reason why "morally controversial" topics should not be avoided. If the fundamental educational goals of public schools are apparent from the European Convention on Human Rights (1994), which establishes pluralistic democratic society and respect for diversity as an ideal, avoidance of "morally controversial" topics may be in direct conflict with this objective. If teachers avoid these topics, pluralism is turned into nothing more than "monism". The "moral shock" that may follow confrontation with facts that oppose one's own particular beliefs is precisely the ground on which it is possible to pursue the objective of tolerance for diversity and life in a pluralistic democratic society. In other words, "moral distress" leads to an awareness of one's own particularity in relation to another particularity.

Following the European Court of Justice's rulings, the aim of public education should not be indoctrination, but rather the acquisition of scientific knowledge that can ultimately also lead to a change in beliefs.

The rulings presented in the present article provide clear instructions regarding the role of public schools and teachers in the context of particular religious and philosophical convictions. As the public educational process must 
be based on the framework of human rights and respect for diversity, the antigender movement should prove that gender equality is an infringement of the idea of equal human rights. Furthermore, it should prove that understanding gender as socially constructed is a false and non-scientific approach to social roles and identities based in gender, as public schools are obliged to base their educational process on scientific findings. It comes as no surprise, therefore, that in many ways - as we have shown in the present article - the anti-gender movement is a struggle over the legitimacy of academic work and - in the populist world of "alternative facts" - an attempt to create "alternative science".

\section{References}

24kul. (2016). Amnesty International: Kaj če bi spremenili spol. 24kul.si. Retrieved from http://24kul. si/amnesti-international-otroci-spremenite-si-svoj-spol.

Anatrella, Tony. (2015). Teorija spola: kulturni izziv [Gender Theory: A Cultural Challenge].

Ljubljana: Novi svet.

Bijelić, N. (2008). Sex education in Croatia: Tensions between secular and religious discourses.

European Journal of Women's Studies, 15(4), 329-343.

Buss, D. E. (2004). Finding the Homosexual in Women's Rights: The Christian Right in International Politics. International Feminist Journal of Politics, 6(2), 257-284.

Cestnik, B. (2013). Kaj je spol? [What Is Gender?] Brane na cesti (blog). Retrieved from http:// branenacesti.blogspot.si/2013/og/kaj-je-spol.html.

Debevec, M. (2015). Teorija spola - prazen strah? [Gender Theory - an Empty Fear?] Radio Ognjišče, April 14. Retrieved from http://radio.ognjisce.si/sl/165/komentarji/16885/.

European Court of Human Rights (2012). Fifth section decision as to the admissibility of Application no. 319/o8. Retrieved from http://hudoc.echr.coe.int/eng\#\{\%22itemid\%22:[\%22001-106382\%22]\}.

Garbagnoli, S. (2017). Italy as a lighthouse: Anti-gender protests between the "anthropological question" and national identity. In R. Kuhar \& D. Paternotte (Eds.), Anti-gender campaigns in Europe: Mobilizing Against Equality (pp. 151- 174). New York, London: Rowman \& Littlefield International. Grabowska, M. (2014). Cultural War or Business as Usual? Recent Instances and the Historical Origins of the Backlash Against Women's Rights and Sexual Rights in Poland. In Heinrich Böll Foundation (Ed.), Anti-Gender Movements on the Rise? Strategising for Gender Equality in Central and Eastern Europe (pp. 64-74). Berlin: Heinrich Böll Foundation.

Graff, A., \& Korolczuk, E. (2017a). "Worse than communism and Nazism put together": War on gender in Poland. In R. Kuhar \& D. Paternotte (Eds.), Anti-gender campaigns in Europe: Mobilizing Against Equality (pp. 175- 194). New York, London: Rowman \& Littlefield International. Graff, A., \& Korolczuk, E. (2017b). Gender as 'Ebola from Brussels': the anti-colonial frame and the rise of illiberal Populism. Signs: Journal of Women in Culture and Society (forthcoming).

Hodžič, A., \& Bijelić, N. (2014). Neo-Conservative Threats to Sexual and Reproductive Health \& Rights 
in the European Union. Zagreb: CESI.

Hodžić, A., \& Štulhofer, A. (2017). Embryo, teddy bear-centaur and the constitution: Mobilizations against "gender ideology" and sexual permissiveness in Croatia. In R. Kuhar \& D. Paternotte (Eds.), Anti-gender campaigns in Europe: Mobilizing Against Equality (pp. 59- 78). New York, London: Rowman \& Littlefield International.

Kodelja, Z. (1995). Laična šola: pro et contra [Secular School: pro et contra]. Ljubljana: Mladinska knjiga.

Korolczuk, E. (2014). The War on Gender from a Transnational Perspective - Lessons for Feminist Strategizing. Berlin: Heinrich Böll Stiftung.

Kovač Šebart, M. (2015). How to evaluate and judge when the moral-educational dimension of instruction is concerned? Review of European studies, 7(11), 138-146.

Kovač Šebart, M., \& Krek, J. (2009). Vzgojna zasnova javne šole [Educational Basis of Public School]. Ljubljana: Pedagoška fakulteta.

Kovač Šebart, M., \& Kuhar, R. (2017). The Pluralisation of Family Life: Implications for Preschool Education. Center for Educational Policy Studies Journal (forthcoming).

Kováts, E., \& Pető, A. (2017). Anti-gender discourse in Hungary: A discourse without a movement? In R. Kuhar \& D. Paternotte (Eds.), Anti-gender campaigns in Europe: Mobilizing Against Equality (pp. 117-132). New York, London: Rowman \& Littlefield International.

Kováts, E., \& Põim, M. (Eds.) (2015). Gender as Symbolic Glue: The Position and Role of Conservative and Far Right Parties in the Anti-Gender Mobilizations in Europe. Budapest: FEPS and FriedrichEbert-Stiftung.

Kuby, G. (2016). The Global Revolution. Destruction of Freedom in the Name of Freedom. Kettering: Angelico Press.

Kuhar, R., \& Patternote, D., (Eds.) (2017). Anti-gender campaigns in Europe: Mobilizing Against Equality. New York, London: Rowman \& Littlefield International.

Kuhar, R. (2015). Playing with Science: Sexual Citizenship and the Roman Catholic Church Counter-

Narratives in Slovenia and Croatia. Women's Studies International Forum, 49(1), 84-92.

Lazaridis, G., Campani, G., \& Benveniste, A. (Eds.) (2016). The Rise of the Far Right in Europe: Populist Shifts and "Othering." London: Palgrave.

Lefort, C. (2001). Mednarodno pravo, človekove pravice in politična akcija [International Law, Human Rights and Political Action]. In J. Šumić - Riha (Ed.), Pravo in politika (pp. 229-241).

Ljubljana: Liberalna akademija.

Mayer, S., \& Sauer, B. (2017). "Gender ideology” in Austria: Coalitions around an empty signifier. In R. Kuhar \& D. Paternotte (Eds.), Anti-gender campaigns in Europe: Mobilizing Against Equality (pp. 23-40). New York, London: Rowman \& Littlefield International.

O’Leary, D. (1997). The Gender Agenda: Redefining Equality. Lafayette: Vital Issue Press. Paternotte, D., \& Kuhar, R. (2017a). “Gender ideology” in movement. In R. Kuhar \& D. Paternotte (Eds.), Anti-gender campaigns in Europe: Mobilizing Against Equality (pp. 1- 22). New York, London: Rowman \& Littlefield International. 
Paternotte, D., \& Kuhar, R. (2017b). The anti-gender movement in comparative perspective. In R. Kuhar \& D. Paternotte (Eds.), Anti-gender campaigns in Europe: Mobilizing Against Equality (pp. 253276). New York, London: Rowman \& Littlefield International.

Paternotte, D. (2015). Blessing the Crowds: Catholic Mobilizations against Gender in Europe. In S. Hark \& P. I. Villa (Eds.), Anti-genderismus: Sexualität und Geschlecht als Schauplätze aktueller politischer Auseinandersetzungen (pp. 129-147). Bielefeld: Transcript.

Plummer, K. (2003). Intimate Citizenship: Private Decisions and Public Dialogues. Seattle, London: University of Washington Press.

Richardson, D. (2000). Rethinking sexuality. London: Sage.

Right to education project (2013). Kjeldsen, Busk Madsen and Pedersen v. Denmark (1976).

Retrieved from http://www.right-to-education.org/resource/kjeldsen-busk-madsen-and-pedersen-vdenmark-1976.

Robinson, K. H. (2008). In the Name of 'Childhood Innocence': A Discursive Exploration of the Moral Panic Associated with Childhood and Sexuality. Cultural Studies Review, 14(2), 113-129. Stambolis-Ruhstorfer, M., \& Tricou, J. (2017). Resisting "gender theory" in France: A fulcrum for religious action in a secular society. In R. Kuhar \& D. Paternotte (Eds.), Anti-gender campaigns in Europe: Mobilizing Against Equality (pp. 79- 98). New York, London: Rowman \& Littlefield International.

Strehovec, T. (2013). Zakonska zveza v perspektivi drugega vatikanskega koncila [Marriage and Family in the Perspective of the Theology of the Second Vatican Council]. Bogoslovni vestnik, 73(2), 233-249.

Villa, P.-I. (2017). “Anti-genderismus”: German angst? In R. Kuhar \& D. Paternotte (Eds.), Antigender campaigns in Europe: Mobilizing Against Equality (pp. 99- 116). New York, London: Rowman \& Littlefield International.

Wodak, R. (2015). The Politics of Fear: What Right-Wing Populist Discourses Mean. London: Sage.

\section{Biographical note}

Roman KunaR, PhD, is a professor at the Department of Sociology, Faculty of Arts, University of Ljubljana, and teaches courses on gender, sexuality, popular culture and everyday life. He holds a $\mathrm{PhD}$ in sociology and is currently the head of the Department of Sociology and the head of its research unit.

Aleš Zobec studied Sociology of Culture, Pedagogy and Comparative Literature at the Faculty of Arts, University Ljubljana. He is a teacher at a secondary school in Ljubljana (Srednja vzgojiteljska šola in gimnazija Ljubljana), where he teaches Preschool Curriculum. 